\title{
Model Dinamis Analisis Keputusan Penanganan Penyebaran Covid-19 Menggunakan Causal Loop Diagram
}

\author{
Husain ${ }^{1}$, Mochammad Wahyudi², M. Safi'i ${ }^{3}$, Muhammad Zarlis ${ }^{4}$ \\ 1,2,3Graduate School of Computer Science, Universitas Sumatera Utara \\ ${ }^{1}$ Fakultas Teknik dan Kesehatan Universitas Bumigora Mataram \\ 2Universitas Bina Sarana Informatika Jakarta \\ ${ }^{3}$ AMIK Tunas Bangsa Pematangsiantar \\ ${ }^{4}$ Faculty of Computer Science and Information Tchnology, Universitas Sumatera Utara \\ e-mail: ${ }^{1}$ husain@universitasbumigora.ac.id, ${ }^{2}$ wahyudi@bsi.ac.id, ${ }^{3}$ m.safii@amiktunasbangsa.ac.id, \\ ${ }^{4}$ m.zarlis@usu.ac.id,
}

\begin{abstract}
\begin{tabular}{llll}
\hline Informasi Artikel & Diterima: 12-06-2020 & Direvisi: 07-08-2020 & Disetujui: 10-02-2021
\end{tabular}
Abstrak

Penyebaran Virus Corona atau Covid 19 sangat cepat dan menjadi pandemi bagi seluruh negara dibelahan dunia ini. Dalam proses pengembangan sangat dinamis dan kompleks terdiri dari banyak komponen yang saling terkait dan beragam, yang masing-masing memiliki tujuan berbeda. Mengenai tantangan yang dinamis dan kompleks di bidang pengembangan penyebaran virus corona, kemampuan mengidentifikasi sangat dibutuhkan dalam meredam peredaran virus. Untuk alasan ini, perlu untuk melihat lebih jauh faktor-faktor apa yang mempengaruhi dan menghambat penyebaran virus dan strategi apa yang diperlukan dan menganalisis hubungan sebab-sebab yang dinamis dinamis dari faktor-faktor ini menggunakan metode pendekatan yang menggunakan sistem Diagram Lingkaran Penyebab atau Causal Loop Diagram (CLD) ). Tujuan dari penelitian ini adalah untuk mendapatkan solusi yang tepat dalam pengambilan keputusan penangan penyebaran virus corona melalui sistem pendekatan dengan model Causal Loop Diagram (CLD).
\end{abstract}

Kata Kunci: Model Dinamis, Causal Loop Diagram (CLD), Covid-19

\begin{abstract}
The spread of Corona Virus or Covid 19 is very fast and has become a pandemic for all countries in this world. In a very dynamic and complex development process consisting of many interrelated and diverse components, each of which has different goals. Regarding the dynamic and complex challenges in the field of developing corona virus spread, the ability to identify is needed to reduce the circulation of the virus. For this reason, it is necessary to look further into the factors that influence and inhibit the spread of the virus and what strategies are needed and analyze the dynamically dynamic causes of these factors using the method of approach that uses the Cause Circle Diagram (CLD) system. ). The purpose of this research is to get the right solution in making decisions to handle the spread of corona virus through a system approach with a Causal Loop Diagram (CLD) model.
\end{abstract}

Keywords: Dinamic Model, Causal Loop Model Diagram (CLD), Covid-19

\section{Pendahuluan}

Perkembangan TIK saat ini mendorong setiap bidang untuk menyediakan informasi terutama dalam sistem pengambilan keputusan untuk meningkatkan, mengembangkan, dan memperbaharui setiap informasi yang disajikan untuk menunjang pelayanan yang baik (Anggrawan, Satria, \& Husain, 2018). IT resource berupa teknologi apa pun yang membantu manusia dalam membuat, mengubah, menyimpan, mengomunikasikan dan/atau menyebarkan informasi (Mao, Liu, Zhang, \& Deng, 2016) (Utami, 2016). TI menyatukan komputasi dan komunikasi berkecepatan tinggi untuk data, suara, dan video (Muhammad Tajuddin, Husain, 2018). Akhir tahun 2019 hingga awal tahun 2020 dunia kesehatan dihebohkan dengan 
merebaknya virus misterius di China yang telah menyebar ke seluruh penjuru dunia. Belakangan diketahui bahwa itu adalah virus corona, atau coronavirus, yang dapat menyebabkan penyakit berbahaya (Chairul Iksan Burhanuddin, 2020). Pada tanggal 11 Februari 2020, WHO memberi nama khusus untuk penyakit yang disebabkan oleh virus corona baru, yaitu COVID-19 yang adalah singkatan dari coronavirus disease 2019 (penyakit virus corona 2019). Belakangan virus corona baru itu juga diberi nama SARS-CoV-2, singkatan dari severe acute respiratory syndrome coronavirus 2 (Chairul Iksan Burhanuddin, 2020).

Secara Global (Global Public Health Emergency) COVID-19 sudah dideklarasikan sebagai Darurat Kesehatan Masyarakat secara oleh Organisasi Kesehatan Dunia (WHO) pada 30 Januari 2020. Corona virus adalah jenis virus yang menyebabkan penyakit mulai dari gejala ringan sampai berat. Ada setidaknya dua jenis corona virus yang diketahui dapat menyebabkan penyakit dengan gejala berat seperti Middle East Respiratory Syndrome (MERS) dan Severe Acute Respiratory Syndrome (SARS). Corona virus Disease 2019 (COVID-19) adalah penyakit jenis baru yang belum pernah diidentifikasi sebelumnya pada manusia. Virus penyebab COVID-19 ini dinamakan Sars-CoV2 . COVID-19 adalah penyakit baru, dimana penelitian terkait penyakit ini masih sedikit. Diperlukan informasi yang berbasis bukti (evidence base) tentang perawatan, pengobatan, maupun informasi lainnya terkait penyakit COVID-19 (Susilo et al., 2020).

Pada bulan maret di perkirakan awal merebaknya virus corona di Indonesia, ubdate data positif corona pada akhir Bulan April 2020, sudah di atas 9000 Kasus terkonfirmasi positif terjangkit virus corona. sekarang ini angkat positif corona sudah diatas 1000an jiwa dan angka meninggal dunia dunia sudah diatas 500 Jiwa, meninggal dunia dia tas 700 jiwa dan yang sembuh diatas 1000 jiwa sumber: www.covid19.go.id. Dalam kurun waktu dua bulan penyebaran virus corona sangat begitu cepat hingga ke seluruh daerah di indonesia. Peran IT resource dalam penangan penyebran virus corona sangat di perlukan.

Banyak faktor yang mempengaruhi cepatnya penyebaran dan penanganan yang dinamis dan kompleks, kemampuan mengidentifikasi sangat dibutuhkan dalam meredam peredaran virus. Untuk alasan ini, perlu untuk melihat lebih jauh faktor-faktor apa yang mempengaruhi dan menghambat penyebaran virus dan strategi apa yang diperlukan dan menganalisis hubungan sebabsebab yang dinamis dinamis dari faktor-faktor ini menggunakan metode pendekatan yang menggunakan sistem Diagram Lingkaran Penyebab (CLD)(Buwana, 2013). Tujuan dari penelitian ini adalah untuk mendapatkan solusi yang tepat dalam pengambilan keputusan penangan penyebaran virus corona melalui sistem pendekatan dengan model Causal Loop Diagram (CLD).

\section{Metodologi \\ Pendekatan Sistem dengan Causal Loop Diagram (CLD)}

Model CLD adalah model yang banyak digunakan dalam pemecahan masalah dengan pendekatan sistem yang mempertimbangkan kompleksitas dinamis dari sistem atau untuk mendukung pendekatan sistem dinamik. Model CLD menekankan perhatiannya kepada hubungan sebabakibat antar komponen sistem yang digambarkan dalam suatu diagram berupa garis lengkung yang berujung tanda panah yang menghubungkan antara komponen sistem yang satu dengan lainnya(Wen Keat \& Musa, 2014).Ujung panah dibubuhi tanda huruf "S" yang menandakan bahwa jika komponen yang mempengaruhi atau sebagai penyebabnya berubah atau meningkat maka komponen yang dipengaruhinya akan berubah atau meningkat juga dan tanda huruf "O" menandakan akbatnya berlawanan dengan pengertian bila komponen yang mempengaruhi meningkat maka komponen yang dipengaruhinya menurun(Buwana, 2013).

Pendekatan memalui model CLD mempunyai beberapa keuntungan antara lain :

1. Mendorong untuk dapat melihat permasalahan secara menyeluruh, baik dari segi cakupan dan waktu sehingga dapat mencegah pemikiran yang sempit.

2. Gambaran rantai hubungan sebabakibat membuat lebih eksplisit dan dasar pemikiran akan lebih baik.

3. Memungkinkan efektifitas komunikasi dapat berjalan dan perwujudan kerja sama tim akan lebih baik.

4. Membantu mengeksplorasi alternative kebijakan dan keputusan sehingga konsekwensinya dapat diantisipasi lebih awal.

5. Memungkinkan keberadaan posisi yang baik untuk mengambil keputusan .

Dalam penyusunan CLD perlu diperhatikan beberapa faktor antara lain :

1. Mengetahui batasan masalah atau ruang lingkup.

2. Dimulai dari komponen yang menarik. 
3. Mempertanyakan tentang pengaruh dari suatu komponen dan hal apa saja yang mempengaruhinya.

4. Menentukan komponen yang terlibat.

5. Penggunaan kata benda terhadap komponen yang dibahas.

6. Menyegerakan tanda "S" dan "O" saat pembuatan diagram.

7. Pembuatan diagram harus realistis, mudah dipahami agar perubahan diagram jika diperlukan dapat dilakukan secara baik.

\section{Literatur Review}

\subsection{Coronavirus disease (COVID-19)}

Korona virus (coronavirus disease) disingkat COVID-19 adalah penyakit menular yang disebabkan oleh SARS-CoV-2, salah satu jenis koronavirus. Penyakit ini mengakibatkan pandemi koronavirus 20192020. Penderita COVID-19 dapat mengalami demam, batuk kering, dan kesulitan bernapas. Sakit tenggorokan, pilek, atau bersin-bersin lebih jarang ditemukan. Pada penderita yang paling rentan, penyakit ini dapat berujung pada pneumonia dan kegagalan multiorgan (Susilo et al., 2020).

Infeksi menyebar dari satu orang ke orang lain melalui percikan (droplet) dari saluran pernapasan yang sering dihasilkan saat batuk atau bersin. Waktu dari paparan virus hingga timbulnya gejala klinis berkisar antara 1-14 hari dengan rata-rata 5 hari. Metode standar diagnosis adalah uji reaksi berantai polimerase transkripsi-balik (rRT-PCR) dari usap nasofaring atau sampel dahak dengan hasil dalam beberapa jam hingga 2 hari. Pemeriksaan antibodi dari sampel serum darah juga dapat digunakan dengan hasil dalam beberapa hari. Infeksi juga dapat didiagnosis dari kombinasi gejala, faktor risiko, dan pemindaian tomografi terkomputasi pada dada yang menunjukkan gejala pneumonia (Chairul Iksan Burhanuddin, 2020).

Mencuci tangan dengan sabun, menjaga jarak dari orang yang batuk, dan tidak menyentuh wajah dengan tangan yang tidak bersih adalah langkah yang disarankan untuk mencegah penyakit ini. Disarankan untuk menutup hidung dan mulut dengan tisu atau siku yang tertekuk ketika batuk. Organisasi Kesehatan Dunia (WHO) dan Pusat Pengendalian dan Pencegahan Penyakit AS (CDC) merekomendasikan kepada orangorang yang menduga bahwa mereka telah terinfeksi untuk memakai masker bedah dan mencari nasihat medis dengan memanggil dokter dan tidak langsung mengunjungi klinik. Masker juga direkomendasikan bagi mereka yang merawat seseorang yang diduga terinfeksi tetapi tidak untuk digunakan masyarakat umum. Belum ada vaksin atau obat antivirus khusus untuk COVID-19; tata laksana yang diberikan meliputi pengobatan terhadap gejala, perawatan suportif, dan tindakan eksperimental. Angka fatalitas kasus diperkirakan antara 1-3\%.

\subsection{Model Pendekatan Sistem}

Model adalah suatu abstraksi dari dunia nyata yang disederhanakan sehingga hanya parameter - parameter dan variabelvariabel yang penting saja yang muncul dalam bentuknya. Sebuah model dapat mencerminkan atau mengabstraksi dari sebuah objek,proses, situasi atau sistem. Secara lebih meluas sebuah model dapat mengungkapkan dan menjelaskan tentang hubungan dari berbagai komponen,aksi dan reaksi dan hubungan sebab akibat (Richardson, 1986). Model yang digunakan diharapkan dapat disesuaikan dengan permasalahan yang dihadapi agar mempermudah pemahaman dan pemecahan masalah yang dihadapi. Model-model yang digunakan dalam pemecahan masalah dapat diilustrasikan dalam bentuk diagram, gambar, tabel matriks dan model - model yang sering digunakan antara lain adalah :

a. Diagram venn, sangat berguna untuk kajian kedudukan suatu supra sistem sistem-sub sistem dan sistem lain.

b. Diagram pohon, sangat membantu dalam mengidentifikasi faktor-faktor apa saja yang berhubungan dengan masalah / siatem yang dikaji.

c. Model kotak hitam yang biasa disebut dengan model masukan - keluaran, yang berarti proses transformasi dari system yang isi dan kegiatan didalamnya tidak diketahui (memang sengaja tidak mau tahu).

d. Model elemen organisasi yang memperhatikan elemen masukan, proses dan keluaran, elemen masukan yang berupa bahan mentah atau sumber daya; proses berupa subsistem organisasi yang mentransformasikan masukan menjadi produk, produk merupakan hasil transformasi masukan yang masih berupa keluaran tahap awal.Keluaran adalah hasil akhir dari proses dan terdapat elemen berupa outcome yang diartikan dampal yang diterima oleh sistem dari keluarannya atau tanggapan / reaksi pengguna / lingkungannya kepada keluaran dari sistem.

e. Diagram pengulangan sebab-akibat, merupakan model yang menekankan pada pertimbangan kompleksitas dinamis dari 
sistem. Model ini menggambarkan hubungan sebab akibat antar variabelvariabel yang bersangkutan dalam bentuk garis lengkung untuk menghubungkan mana yang merupakan variable penyebab dan mana yang merupakan variabel akibat.

\section{Pembahasan}

3.1. Analisis peningkatan penyebaran dan penghambat penyebaran Virus Corona

Virus corona pandemi global COVID-19 yang melanda negara -negara di dunia termasuk Indonesia telah berdampak besar bagi sejumlah aspek. Mulai dari lingkungan ekonomi, sosial, hingga mempengaruhi kondisi alam. Dalam hitungan bulan, dahsyatnya penyebaran virus corona telah mengubah cara hidup dan kondisi masyarakat di indonesia. Virus yang pertama kali menyerang Wuhan, China itu kini secara gelobal telah menelan ratusan ribuan korban jiwa dan membuat satu jutaan ribu juwa jatuh sakit terjangkit virus corona. Tentunya para ilmua berlomba-lomba dalam meneliti terkait vaksin maupun cara-cara lain yang dapat membantu penanganan penyebaran virus corona. Peran TIK saat ini untuk bisa membantu penanganan penyebaran virus korona sangat di perlukan, sehingga dalam penelitian membuat sebuah model penyebaran dalam menihal sebab akibat dari beberapa faktor yang terlibat, baik itu faktor yang mempengaruhi peningkatan penyebaran virus maupun faktor yang dapat menghambat penyebaran virus. Seperti yang terlihat dalam diagram causal loop diagram di bawah ini:

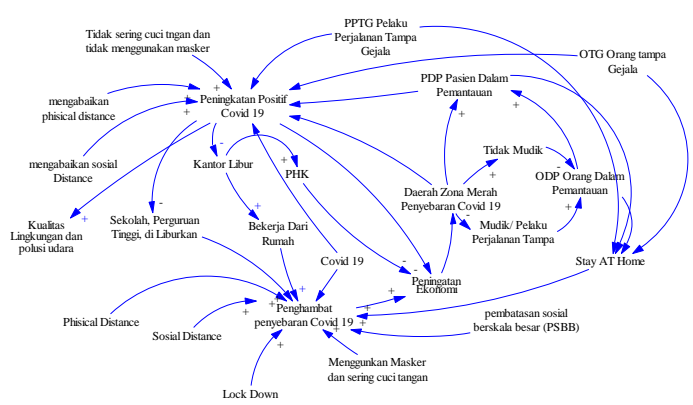

\section{Gambar 1 : Causal Loop Diagram Sebab akibat dalam penyebaran virus corona}

Dalam usaha penangan penyebaran covid-19 tentunya mengidentifikasi beberapa faktor yang mempengaruhi peningkatan penyebaran virus yang terkonfirmasi positif. Hal yang paling ber[engaruh terasa terhadap keberadaan virus ini adalah Ekonomi, baiik secara nasional, local (Daerah) maupun secara pribadi. Sekolah dan Kampus diliburkan (Belajar secara Daring), Kantor memberkalukan Work From Home (WFH) , Mudik dilarang, pasar tutup, mall tutup, penerbngan di stop, pelabuhan ditutup dan semua hal di batasi. Dari gambar diatas berikut ini diuraikan dalam bentuk tabel untuk menjelaskan sebab akibat dari faktor yang terlibat dalam penyebaran virus corona.

Table 1 Tabel Sebab akibat

\begin{tabular}{|c|c|c|}
\hline No & $\begin{array}{c}\text { Faktor-Faktor yang } \\
\text { pempengaruhi } \\
\text { peningkatan positif } \\
\text { virus corona }\end{array}$ & Sebab Akibat \\
\hline 1 & $\begin{array}{l}\text { Tidak Sering Mencuci } \\
\text { tangan }\end{array}$ & \multirow{6}{*}{$\begin{array}{l}\text { Berpengaruh } \\
\text { Positif dalam } \\
\text { peningkatan } \\
\text { jumlah } \\
\text { terjangkit virus } \\
\text { corona }\end{array}$} \\
\hline 2 & $\begin{array}{l}\text { Mengabaikan Fisikal } \\
\text { Distance }\end{array}$ & \\
\hline 3 & Mengabaikan Sosial & \\
\hline 4 & $\begin{array}{ll}\text { Pasien } & \text { Dalam } \\
\text { Pemantauan } & \end{array}$ & \\
\hline 5 & $\begin{array}{l}\text { Orang yang datang } \\
\text { dari zona Merah } \\
\text { sehingga di tetapkasn } \\
\text { sebagai ODP, PDP, } \\
\text { PPTG, OTG }\end{array}$ & \\
\hline 6 & $\begin{array}{lr}\text { Jarang } & \text { mencuci } \\
\text { tangan dan } \quad \text { kelur } \\
\text { rumah } \\
\text { menggunakan masker }\end{array}$ & \\
\hline 8 & $\begin{array}{l}\text { Peningkatan Positif } \\
\text { Virus Corona }\end{array}$ & \multirow{3}{*}{$\begin{array}{l}\text { Berpengaruh } \\
\text { Negatif } \\
\text { terhadap } \\
\text { sekolah, kantor } \\
\text { dan } \\
\text { perusahaan } \\
\text { lainnya } \\
\text { Tranfortasi, } \\
\text { Wisata dan } \\
\text { Swalayan (Mal, } \\
\text { Pasar dll) } \\
\text { Berpengaruh } \\
\text { Positif terhadap } \\
\text { lingkungan dan } \\
\text { udara }\end{array}$} \\
\hline 9 & $\begin{array}{l}\text { Peningkatan } \\
\text { Virus Corona }\end{array}$ & \\
\hline 7 & Kualitas Lingkungan & \\
\hline No & $\begin{array}{c}\text { Faktor-Faktor yang } \\
\text { pempengaruhi } \\
\text { peningkatan } \\
\text { penurunan atau } \\
\text { penghambat } \\
\text { penyeberan virus } \\
\text { corona }\end{array}$ & Sebab Akibat \\
\hline 2 & $\begin{array}{l}\text { Selalu } \quad \text { physical } \\
\text { distance } \\
\text { Selalu menerapkan } \\
\text { social distance }\end{array}$ & \multirow{2}{*}{$\begin{array}{l}\text { Berpengaruh } \\
\text { Positif terhdap } \\
\text { penghambat } \\
\text { penyebaran } \\
\text { virus corona }\end{array}$} \\
\hline 3 & $\begin{array}{l}\text { Sering mencuci tangan } \\
\text { dan menggunakan }\end{array}$ & \\
\hline
\end{tabular}




\begin{tabular}{ll} 
& Masker saat \\
berpergian/Keluar & rumah \\
4 & Lock Down Wilayah \\
5 & PSBB Pembatasan \\
& Sosial B Bersekala \\
& Besar \\
6 & Stay At Home \\
7 & Kerja dari rumah \\
8 & Belajar dari rumah \\
\hline
\end{tabular}

\section{Kesimpulan}

Dalam proses penanganan penyebaran virus corona covid-19 merupan system yang kompleks dan dinamis. Terdapat banyak komponen yang saling berinteraksi dan pemperngaruhi antara satu dengan yang lainnya. Terdapat banyak faktor-faktor yang memiliki kepentingan yang berbeda serta berbagai faktor yang memiliki tujuan kepentingan yang berbeda. Dari hasil penelitian ini sangat jelas faktor-faktor yang mempengaruhi peningkatan orang yang terjangkit virus corona dan faktor-faktor yang mempengaruhi penghambat dalam penyebaran virus corona. Dalam mengambarkan model penyebaran dan penangan virus corona peneliti menggunakan model Causual Loop Diagram, dengan harapan dapat membantu pemerintah dan terkait dalam memahami hubungan yang kompleks dalam pengambilan keputusan. Model CLD ini digunakan untuk mengidentifikasi akar penyebab akibat masalah yang kompleks dan daya pengaruh dari sistem sistem penangan penyebaran virus. Model ini digunakan sebagai dasar untuk membangun sebuah model simulasi yang dapat digunakan untuk mengembangkan dan menguji kebijakan manajemen alternatif.

\section{Referensi}

Anggrawan, A., Satria, C., \& Husain, H. (2018). Smart Campus: Model Baru Enterprise Architecture STMIK Bumigora Mataram dalam Manajement Tata Kelola TIK Berbasis TOGAF ADM. Jurnal Mantik Penusa, 2(2), 127-136. Retrieved from http://e-

jurnal.pelitanusantara.ac.id/index.php/ma ntik/article/view/497
Buwana, E. (2013). Membuat Causal Loop Diagram untuk system dynamic dengan kasus Kemacetan dan Kondisi rumah tinggal.

Chairul Iksan Burhanuddin, M. N. A. (2020). Ancaman Krisis Ekonomi Global dari Dampak Penyebaran Virus Corona (Covid-19). Akmen, 17(1).

Mao, H., Liu, S., Zhang, J., \& Deng, Z. (2016). Information technology resource, knowledge management capability, and competitive advantage: The moderating role of resource commitment. International Journal of Information Management, 36(6), 1062-1074. https://doi.org/10.1016/j.ijinfomgt.2016.07 .001

Muhammad Tajuddin, Husain, N. N. J. (2018). Preservasi Naskah Kuno Sasak Lombok Berbasis Digital dan Website. Jurnal Teknologi Informasi Dan IImu Komputer, $5(4)$, 445. https://doi.org/10.25126/jtiik.201854787

Richardson, G. P. (1986). Problems with causal-loop diagrams. 2(2), 158-170.

Susilo, A., Rumende, C. M., Pitoyo, C. W., Santoso, W. D., Yulianti, M., Sinto, R., ... Cipto, R. (2020). Coronavirus Disease 2019: Tinjauan Literatur Terkini Coronavirus Disease 2019: Review of Current Literatures. Jurnal Penyakit Dalam Indonesia, 7(1), 45-67.

Utami, I. (2016). Implementasi E-Learning Menggunakan CMS Moodle Untuk Meningkatkan Aktivitas Belajar Siswa. Jurnal Komputer Terapan, 2(2), 169-178.

Wen Keat, K., \& Musa, N. B. (2014). Responsible tourism system dynamic planning model for rural area. 2014 the 5th International Conference on Information and Communication Technology for the Muslim World, ICT4M 2014, 3-8. https://doi.org/10.1109/ICT4M.2014.7020 679 